\title{
. . . as UK agency cuts staff to prepare for privatization
}

London. Plans by the British government to privatize AEA Technology, the science and engineering division of the United Kingdom Atomic Energy Authority (UKAEA), took the next step forward last week with the publication of the Atomic Energy Authority Bill.

No decisions have been taken on the precise form that the privatization will take. "The bill deliberately leaves a number of options open so that we can make decisions nearer the time of sale," says Richard Page, the parliamentary under secretary of state at the Department of Trade and Industry.

In welcoming the bill, Sir Anthony Cleaver, the chief executive of AEA Technology said it will give the company freedom to expand its commercial activities.

But the move is being disputed by labour unions representing UKAEA staff, because they say it will lead to further cuts in research and technical staff that have already dramatically reduced the scientific capabilities of what has been Britain's main nuclear research and development organization since 1954.

Last year, the UKAEA, was formerly split into two as part of a long-promised privatization strategy. The UKAEA Government Division, will remain a government authority for nuclear facilities. The other, AEA

\section{new lease of life}

opposed to any reprocessing at Dounreay on the grounds that allowing reprocessing outside the United States would weaken its anti-proliferation policy.

But the talks are far from any likely action. The DoE will include the "Dounreay option" in its environmental impact statement. But it will not necessarily be accepted as the preferred option for dealing with $\mathrm{HEU}$ waste from research reactors. Even if agreement on reprocessing is reached with Dounreay, it is unlikely to take effect until 1996, by when various research reactors may have found solutions of their own.

Indeed, some reactors have now started talking to Dounreay independently about reprocessing their spent HEU fuel as they already have acute storage problems, and may be unable wait for the United States to make a firm decision. Dounreay has been encouraging such discussions because its D1204 plant, previously used for handling waste from fast breeder reactors, is threatened with decommissioning because of a lack of contracts.

The DoE wants to prevent the research reactors from negotiating directly with the UKAEA, without meeting its own conditions.

Alison Abbott
Technology, is being spun off as a general science and engineering service business. It now has an annual turnover of $£ 250$ million (US $\$ 406$ million), and made a profit of $£ 10$ million last year but only about half of its revenue comes from the nuclear industry through competitive tendering for decommissioning and safety contracts. The rest comes from general high technology consultancy and development work.

The government division holds approximately $£ 8$ billion of assets, which include nuclear and other facilities at Dounreay, Windscale, Risley, Harwell, Culham and Winfrith. It will remain responsible for sites, nuclear facilities, and awarding decommissioning contracts to companies including AEA Technology.

Nuclear research will not disappear completely. The agency still provides between $£ 12$ and $£ 13$ million a year for fusion research at Culham, for example, and works closely with the Joint European Torus project. But when this is compared with budgets of around $£ 200$ million in the late eighties, it is obvious some research has "fallen through the cracks" says Dr Derek Pooley, chief executive of the government division.

The British government argues that as the nuclear industry is now fully mature, research funding should be allocated on strictly commercial principles. "There are very strong differences of opinion whether what we have done in Britian is right or not," says Pooley.

But labour unions such as the Institute of Professionals, Managers and Scientists (IPMS) claim that moves to privatize AEA Technology undermines long-term planning in the industry. "We do not agree that the market should determine the research because it is very difficult to plan any longer than a few years," says Tony Wickett, Branch Secretary for IPMS.

Nick Parsons, head of media relations for AEA Technology, says the company's research budget is comparable to that of its competitors, five per cent of its annual turnover, or about $£ 12.5$ million.

The union is concerned about the other effect of government and the nuclear industry reducing research spend, namely staff numbers have been reduced since the 1980 s from 14,000 to a total of just over 7000 . The government division is not expecting any more redundancies but AEA Technology admits it is seeking $300-400$ redundancies before the start of the next financial year (1 April 1995). "It is always a matter of regret but the only future for our business and staff is if we can be competitive," says Parsons. "It is essential to our survival, whether or not we are privatized."

Fiona Gammie

\section{Russia links higher science funding to structural reforms}

Moscow. The Russian cabinet has agreed to set up a new, streamlined Commission on Science Policy, headed by the prime minister, Viktor Chernomyrdin. The 20-member commission will be responsible for identifying research priorities.

The decision was taken a week after President Boris Yeltsin, in his annual address to the Russian Parliament, had admitted that public funds allocated to science "are insufficient to maintain the current level and amount of fundamental research". He urged a "strucIMAGE
UNAVAILABLE whole scientific
FOR
community".
In an subsequent COPYRIGHT address to the cabiREASONS net, the Minister for Science and Technology Policy, Boris Saltykov, empha-

Yeltsin: research sized that the govbudget 'insufficient'. ernment has cut funding for science by 80 per cent over the past four years, leading to a drop of onethird in the number of scientists employed.

In some fields, he said, the losses are irreparable. But one of the key reasons for the current crisis was the delay in implementing structural reforms. Although promising to increasing funding to three per cent of the total federal budget in 1996, he said that this should be accompanied by the closure of certain research centres, and greater efforts by the research community to adapt to the conditions of the market.

Indeed, the day after the cabinet meeting, the state Duma (parliament), in discussing the 1995 budget for the third time, agreed to approve a significant increase in funding of science. Their decision took the form of an amendment proposing to raise the research budget by a further 1,700 billion rubles from its current planned level of 5,400 billion rubles (US $\$ 1.17$ billion) - and to take this money out of government administration.

But Saltykov subsequently dismissed the proposal as a "crazy idea". Andrei Zakharov, head of the office responsible for the Committee for Education, Culture and Science, expressed his "horror" at the Duma's move. "Naturally I want Russian science to be healthy - but not at the price of destroying the state machine."

The state Duma is expected to take a final vote on the research budget tomorrow (10 March). It is widely expected to reject the calls for an extra 1,700 billion rubles but to approve an increase of 300 billion rubles on the figures proposed by the government.

Carl Levitin 